\title{
PENGARUH PEMBINAAN PEMERINTAH TERHADAP PERTUMBUHAN USAHA YANG DIMEDIASI OLEH SIKAP PADA PERTUMBUHAN USAHA, NORMA SUBYEKTIF DAN PERCEIVED BEHAVIOR CONTROL PENGUSAHA UKM
}

\author{
Ni Made Suci \\ Jurusan Ekonomi \\ Universitas Pendidikan Ganesha Singaraja \\ Singaraja, Bali, Indonesia \\ e-mail : madesuci-bali@yahoo.com
}

\begin{abstract}
Abstrak
Tujuan penelitian ini adalah menguji pengaruh pembinaan pemerintah terhadap pertumbuhan usaha yang dimediasi oleh sikap pada pertumbuhan usaha, norma subyektif, perceived behavior control/PBC pengusaha pada UKM di Provinsi Bali. Penelitian ekplanatori ini menggunakan pendekatan kuantitatif untuk menghasilkan temuan yang bersifat konklusif. Jumlah sampel sebanyak 180 pengusaha yang ditetapkan berdasarkan teknik purposive sampling. Teknik pengumpulan data adalah survey dengan instrumen kuesioner. Teknik analisis data dengan Structural Equation Modelling (SEM). Hasil penelitian menunjukkan bahwa: (1) Pembinaan pemerintah berpengaruh positif dan signifikan terhadap sikap pada pertumbuhan usaha, norma subyektif dan PBC pengusaha (2) Norma subyektif dan PBC pengusaha berpengaruh positif dan signifikan terhadap pertumbuhan usaha UKM. (3) Sikap pada pertumbuhan berpengaruh signifikan terhadap pertumbuhan usaha. (4) Norma subyektif dan PBC terbukti memediasi pengaruh pembinaan terhadap pertumbuhan usaha. (5) Sikap pada pertumbuhan usaha tidak terbukti memediasi pengaruh pembinaan terhadap pertumbuhan usaha pada UKM. Perlu program pembinaan yang tepat secara berkelanjutan untuk membentuk sikap dan perilaku positif pengusaha dalam mengembangkan usaha.
\end{abstract}

Kata kunci: pembinaan, sikap pada pertumbuhan usaha, norma subyektif, perceived behavior control dan pertumbuhan usaha

\begin{abstract}
The purpose of this study was to test the effect of government guidance on business growth of SMEs mediated by entrepreneur's attitude toward business growth, subjective norms, perceived behavioral control / PBC to SMEs in the Province of Bali. This explanatory research uses a quantitative approach to generate conclusive findings. The total sample of 180 entrepreneurs who are determined based on purposive sampling technique. Data collection techniques are survey by questionnaire. Data analysis techniques with Structural Equation Modelling (SEM). The results showed that: (1) Guidance government have significant and positive effect on the entrepreneur's attitude toward business growth, subjective norm and PBC (2) Entrepreneur's subjective norm and PBC have positive and significant impact on the growth of SMEs (3) The entrepreneur's
\end{abstract}


attitude toward business growth does not significantly affect on business growth of SMEs. (4) The subjective norm and PBC proved to mediate the effect of govermen guidance on business growth (5) The entrepreneur's attitude toward business growth is not proven to mediate the effect of govermen guidance on business growth in SMEs. Need proper and continuing coaching program to form positive attitudes and behavior of entrepreneur,s in developing businesses.

Keywords: coaching, attitude to business growth, subjective norm, perceived behavioral control and business growth

\section{PENDAHULUAN}

Pengembangan usaha mikro, kecil dan menengah (UKM) menjadi prioritas pembangunan ekonomi nasional karena usaha tersebut mempunyai kontribusi secara sosial dan ekonomi. Kontribusi sosial UKM dalam menyerap tenaga kerja pada tahun 2013 mencapai 89\% dan sebagai penyumbang sebesar $56,6 \%$ bagi product domestic bruto (PDB) perekonomian Indonesia (Kementerian UKM dan Koperasi, 2013). Data tersebut menunjukkan bahwa kontribusi sosial UKM sudah cukup tinggi sedangkan kontribusi ekonominya masih perlu ditingkatkan. Peningkatan kontribusi UKM dalam perekonomian dapat dilakukan dengan meningkatkan pertumbuhan dan besaran usahanya sesuai dengan potensi daerah masing-masing (Inggarwati dan Kaudin, 2010; Munizu, 2010).

Usaha yang tumbuh ditandai dengan meningkatnya jumlah: tenaga yang digunakan, modal, penjualan produk dan daerah pemasaran serta laba secara berkesinambungan. Keterbatasan modal, kurangnya akses terhadap sumber daya produktif, pasar, akses teknologi selama ini selalu dipandang sebagai faktor penyebab tidak tumbuhnya usaha pada UKM. Dalam kenyataannya, lambatnya pertumbuhan usaha pada UKM, diduga disebabkan faktor perilaku pengusahanya. Keengganan pengusaha mengembangkan usahanya karena ingin mempertahankan kepemilikan dan kendali administratif sehingga pengusaha tidak merealisasi potensi pertumbuhan usahanya secara optimal Wilklund et al., 2003). Hal ini menunjukkan perlunya mengeksplorasi dan menguji faktor-faktor yang mempengaruhi perilaku pengusaha dalam mengembangkan usahanya.

Tidak adanya pembedaan yang jelas antara pemilik dan pengelola UKM sehingga keputusan bisnis pada UKM tergantung pada ability, capability, dan motivasi personal pemiliknya (Walker dan Brown, 2004; Kuncoro, 2007). Berbagai program pembinaan telah dilakukan oleh pemerintah untuk meningkatkan pertumbuhan usaha pada UKM. Kenyataannya program tersebut hanya untuk merealisasi program tahunan masing-masing instansi terkait, cenderung bersifat tumpang tindah, tidak ada keseragaman indikator hasil sehingga pengusaha merasa hanya sebagai obyek pembinaan tanpa ada solusi terhadap permasalahan yang dihadapi dalam pengembangan usahanya. Hal ini menunjukkan perlunya program pembinaan yang dapat membentuk dan merubah pola pikir, 
etos kerja dan perilaku pengusaha dalam mengelola perusahaan secara efektif, efisien dan berkesinambungan.

Penelitian-penelitian sebelumnya sebagian besar bertujuan untuk menguji pengaruh sejumlah faktor keuangan dan pembinaan terhadap pertumbuhan usaha pada UKM. Sedangkan bagimana pembinaan pemerintah mempengaruhi perilaku pengusaha dalam pengembangan usahanya secara berkelanjutan masih menunjukkan kesenjangan secara teori dan empiris (Inggarwati dan Kaudin,2010). Kesimpulan studi Southey (2011) menyarankan bahwa Theory of Planned Behavior (TPB) sangat sesuai untuk menjelaskan perilaku pengambilan keputusan bisnis pada UKM. Kerangka kerja TPB digunakan sebagai dasar teori untuk menjelaskan perilaku bisnis pada UKM dengan menterjemahkan variabel sikap terhadap perilaku, norma subyektif dan perceived behavior control dan hubungan antar variabel tersebut ke dalam aspek-aspek pengelolaan usaha pada UKM.

Sikap merupakan predisposisi untuk bertindak. Sikap terhadap pertumbuhan usaha merupakan respons evaluatif individu terhadap risiko dan return dalam berbisnis (Zhao et al., 2005; Seagel et al., 2005; Collie dan Spark, 2000; Ainuddin dan Sa'odah 2001; Ali 2011). Sebagai respon evaluatif, sikap berperan penting dalam mempengaruhi perilaku seseorang. Hasil penelitian East (1993) membuktikan sikap investor berpengaruh terhadap keputusan investasi sedangkan Thompson dan Panayiotopoulos (1999) membuktikan sikap tidak berpengaruh terhadap keputusan bisnis pada UKM, karena perubahan sikap lebih cepat terjadi pada bisnis kecil dibandingkan dengan perusahaan besar.

Norma subyektif adalah persepsi seseorang terhadap dukungan orangorang penting baginya dalam berperilaku tertentu (Granovetter,1985; Aldrich dan Fiol, 1994; Ajzen, 2005; Baron dan Byrne, 2005). Norma subyektif berpengaruh terhadap[ pertumbuhan usaha (Mitchell et al., 2002). Hal ini karena UKM pada umumnya berlokasi di daerah pedesaan sehingga faktor norma sosial dan budaya mempengaruhi perilaku pengusaha dalam mengembangkan usahanya (Venkatesh dan Davis (2000); Alleyne dan Tracey 2011). Sedangkan Davis et al., (1989); Wijaya, (2008) membuktikan bahwa norma subyektif tidak berpengaruh terhadap perilaku wirausaha baik secara langsung maupun melalui niat berperilaku wirausaha. Persepsi dukungan orang-orang penting bagi pengusaha mempengaruhi norma subyektif pengusaha dalam mengembangkan usahanya.

Perilaku terkadang sulit diwujudkan walaupun adanya sikap yang positif dan norma subyektif yang sesuai sehingga perlu mempertimbangkan Perceived behavior control/PBC untuk mewujudkan suatu perilaku. Mengacu pada Bandura (1986), bahwa konsep self efficacy sama dengan konsep PBC. Self efficacy adalah keyakinan seseorang akan kemampuannya dalam mengorganisir perilaku tertentu untuk mencapai tujuan yang telah ditetapkan (Barbosa et al., 2007). Self efficacy bersifat task specific sehingga pengukurannya harus didasarkan pada tugas dan perilaku Jurnal IImu Sosial dan Humaniora | 707 
tertentu. Self efficacy bagi seorang wirausaha disebut entrepreneurial selfefficacy (Chen, et al, 1998). Hasil penelitian Stajkovic dan Luthans (1989); Boyd dan Vozikis (1994) membuktikan bahwa self efficacy berpengaruh terhadap kinerja. Sedangkan Wijaya (2008); Adam (2012) membuktikan bahwa PBC yang dioperasionalisasikan sebagai self efficacy tidak berpengaruh terhadap perilaku wirausaha.

Berdasarkan uraian tersebut di atas, Pembinaan pemerintah diharapkan dapat merubah perilaku pengusaha dalam pengembangan usahanya. Perubahan perilaku pengusaha dalam mengembangkan usahanya diharapkan dapat meningkatkan pertumbuhan usaha pada UKM, sehingga penting dan menarik untuk menguji pengaruh mediasi sikap pada pertumbuhan usaha, norma subyektif dan PBC pengusaha dalam hubungan pembinaan terhadap pertumbuhan usaha pada UKM.

\section{METODE}

Rancangan penelitian ini adalah penelitian ekplanatori yang dimaksudkan untuk memberikan penjelasan terhadap fenomena pertumbuhan usaha pada UKM di Provinsi Bali. Adapun variabel penelitian ini: 1) pembinaan pemberian bantuan permodalan, penetapan regulasi dan pelatihan untuk meningkatkan pertumbuhan usaha. Pembinaan pemerintah diukur dengan persepsi pengusaha terhadap kesesuai pembinaan dengan kebutuhan kebutuhan pengusaha dalam mengembangkan usahanya, Kemudahan prosedur dan keyakinan akan tercapainya tujuan pengambangan usaha. 2) sikap terhadap pertumbuhan usaha adalah Respon evaluatif pengusaha terhadap pertumbuhan usahanya. Variabel ini diukur dengan penilaian positif dan negatif pengusaha terhadap pertumbuhan usahanya. 3) norma subyektif adalah persepsi dukungan orang- orang penting dalam pengembangan usaha. Variabel ini diukur dengan persepsi dukungan keluarga, rekan bisnis, pemasok dan masyarakat sekitar. 4) perceived behavior control adalah persepsi pengusaha terhadap kemampuannya dalam mengembangkan usahanya. Variabel ini diukur dengan indikator kemampuan mengidentifikasi peluang, mengelola sumber daya, membina hubungan dengan pihak terkait dan mempunyai ketrampilan pada bidang usaha yang dikembangkan. 5) pertumbuhan usaha adalah persepsi pengusaha terhadap pertumbuhan usahanya. Variabel ini diukur dengan peningkatan jumlah unit usaha, tenaga kerja, modal, volume penjualan dan peningkatan laba.

Populasi penelitian ini adalah pengusaha UKM di Provinsi Bali. Sampel ditetapkan secara purposive sampling dengan pertimbangan: a) pengusaha UKM yang memiliki ijin usaha, b) telah mendirikan usaha minimal dalam tiga tahun, c) mendapat pembinaan. Berdasarkan kreteria tersebut, jumlah sampel ditetapkan sebanyak 180 pengusaha mengacu pada Hair et al. (2006). Pengumpulan data dilakukan dengan metode survey dengan instrumen kuesioner yang dikembangkan berdasarkan skala Likert. Kemudian data dianalisis dengan teknik analisis deskriptif dan Structural Equation Modelling (SEM).

Jurnal IImu Sosial dan Humaniora | 708 
HASIL DAN PEMBAHASAN

Tabel 01 Hasil Uji Validitas Convergent

\begin{tabular}{|l|c|c|}
\hline \multicolumn{1}{|c|}{ Variabel } & $\begin{array}{c}\text { Total } \\
\text { Estimate }\end{array}$ & AVE \\
\hline Pembinaan & 1,431 & 0,5 \\
\hline Sikap pada Pertumbuhan Usaha & 1,643 & 0,5 \\
\hline Norma Subyektif & 2,798 & 0,7 \\
\hline Perceived Behavior Control & 2,414 & 0,6 \\
\hline Pertumbuhan Usaha & 2,474 & 0,5 \\
\hline
\end{tabular}

Berdasarkan data pada Tabel 01, diketahui semua nilai AVE lebih besar atau sama dengan 0,5 yang berarti semua variabel penelitian dinyatakan

valid. Selanjutnya hasil pengujian reliabilitas konstruk ditunjukkan pada Tabel 02 sebagai berikut.

Tabel 02 Nilai Reliabilitas Konstruk

\begin{tabular}{|l|l|c|}
\hline No & \multicolumn{1}{|c|}{ Variabel } & Nilai Reliabilitas \\
\hline 1 & Pembinaan Pemerintah & 0,51998 \\
\hline 2 & Sikap pada Pertumbuhan Usaha & 0,57924 \\
\hline 3 & Norma subyektif & 0,80353 \\
\hline 4 & PBC & 0,73829 \\
\hline 5 & Pertumbuhan Usaha & 0,62776 \\
\hline
\end{tabular}

Data pada Tabel 02 dikatakan reliabel. Sedangkan hasil menunjukkan bahwa nilai cronbach's pengujian Goodness of Fit Model alpha dan composite reliability ditunjukkan pada Tabel 03 sebagai coefficients untuk semua variabel di atas berikut.

0,5 berarti semua variabel penelitian

Tabel 03 Koefisien Goodness of Fit

\begin{tabular}{|c|c|}
\hline Goodness of Fit Index & Cut off Value \\
\hline Chi Square $\left(\mathrm{X}^{2}\right)$ & 265,765 \\
\hline Probabilitas & 0,000 \\
\hline CMIN/DF & 2.000 \\
\hline G F I & .9400 \\
\hline A G F I & .9180 \\
\hline T L I & .9700 \\
\hline C F I & .9780 \\
\hline R M S E A & .0710 \\
\hline
\end{tabular}


Data pada Tabel 03 menunjukkan nilai sesuai dengan yang dipersyaratkan dalam pengujian model dengan teknik SEM, sehingga model yang diajukan baik dan sesuai. Hasil pengujian hipotesis penelitian ditunjukkan pada Tabel 04 sebagai berikut.

Tabel 4.6 Hasil Pengujian Hipotesis Penelitian

\begin{tabular}{|c|c|l|c|c|c|}
\hline No & $\begin{array}{c}\text { Variabel } \\
\text { pengaruh }\end{array}$ & Variabel yg dipengaruhi & $\begin{array}{c}\text { Estimate } \\
\text { (koef } \\
\text { jalur) }\end{array}$ & $\begin{array}{c}\text { P- } \\
\text { Value }\end{array}$ & $\begin{array}{c}\text { Ket . } \\
(\alpha=5 \%)\end{array}$ \\
\hline 1 & Pembinaan & $\begin{array}{l}\text { Sikap pd pertumbuhan } \\
\text { usaha }\end{array}$ & .411 & 0,003 & Signifikan \\
\hline 2 & Pembinaan & Norma subyektif & .184 & 0,014 & Signifikan \\
\hline 3 & Pembinaan & PBC & .136 & 0,045 & Signifikan \\
\hline 4 & Pembinaan & Pertumbuhan usaha & .135 & 0,159 & $\begin{array}{c}\text { Tidak } \\
\text { Signifikan }\end{array}$ \\
\hline 5 & $\begin{array}{c}\text { Sikap pd } \\
\text { pertumbuhan } \\
\text { usaha }\end{array}$ & Pertumbuhan usaha & .040 & 0,757 & $\begin{array}{c}\text { Tidak } \\
\text { Signifikan }\end{array}$ \\
\hline 6 & $\begin{array}{c}\text { Norma } \\
\text { subyektif }\end{array}$ & Pertumbuhan usaha & .355 & 0,005 & Signifikan \\
\hline 7 & PBC & Pertumbuhan usaha & .505 & 0,000 & Signifikan \\
\hline 8 & Pembinaan & $\begin{array}{l}\text { Pertumbuhan usaha } \\
\text { melalui sikap pada } \\
\text { pertumbuhan usaha }\end{array}$ &, 300 & $\begin{array}{c}0,159 \\
\text { dan } \\
0,757\end{array}$ & $\begin{array}{c}\text { Signifikan } \\
\text { Memediasi }\end{array}$ \\
\hline 9 & Pembinaan & $\begin{array}{l}\text { Pertumbuhan usaha } \\
\text { melalui norma subyektif }\end{array}$ & 0,590 & $\begin{array}{c}0,014 \\
\text { dan } \\
0,005\end{array}$ & $\begin{array}{c}\text { Signifikan } \\
\text { Mediasi }\end{array}$ \\
\hline 10 & Pembinaan & $\begin{array}{l}\text { Pertumbuhan usaha } \\
\text { melalui PBC }\end{array}$ & 0,614 & $\begin{array}{c}0,045 \\
\text { dan } \\
0,000\end{array}$ & $\begin{array}{c}\text { Signifikan } \\
\text { Mediasi }\end{array}$ \\
\hline
\end{tabular}

1. Pengaruh Pembinaan terhadap Pertumbuhan Usaha

Pembinaan

berpengaruh signifikan terhadap pertumbuhan usaha. Pembinaan adalah upaya untuk menghasilkan perubahan sikap dan tingkah laku (Rivai dan Sagala, 2010). Perubahan perilaku pengusaha UKM maksudnya adalah bertambahnya pengetahuan, keahlian, ketrampilan dan perubahan sikap pengusaha dalam mengelola usahanya. Pengaruh pembinaan terhadap pertumbuhan usaha positif tetapi tidak signifikan, maksudnya semakin sering pembinaan diberikan maka akan meningkatkan pertumbuhan usaha pada UKM. Pembinaan tidak berpengaruh signifikan terhadap pertumbuhan usaha diduga karena sejumlah faktor yang mempengaruhi pelaksanaan pembinaan tersebut. Pembinaan akan berpengaruh pada pertumbuhan usaha bila sesuai dengan kebutuhan pengusaha dalam mengembangkan usahanya. Hasil penelitian ini bertentangan dengan

Jurnal IImu Sosial dan Humaniora | 710 
Premaratne, (1999); Sihotang (2003); Okunlola, (2011).

2. Pengaruh pembinaan terhadap sikap pada pertumbuhan usaha.

Pembinaan

pemerintah

berpengaruh signifikan terhadap sikap pada pertumbuhan usaha, menunjukkan bahwa pembinaan yang diberikan pemerintah mampu merubah sikap pengusaha terhadap pertumbuhan usahanya. Temuan ini mendukung kesimpulan studi Rivai dan Sagala (2010) bahwa pembinaan bertujuan untuk merubah sikap dan perilaku pengusaha dalam mengelola usahanya. Temuan juga didukung analisis deskriptif sebanyak 138 atau $76 \%$ pengusaha setuju bahwa tujuan pengelolaan usaha adalah untuk mencapai tingkat pertumbuhan yang tinggi dan berdampak positif terhadap lingkungan sekitarnya. Tingkat pertumbuhan yang tinggi secara berkesinambungan dapat dicapai dengan mengelola usaha secara fektif dan efisien, sesuai dengan rencana yang telah ditetapkan.

3. Pengaruh pembinaan pemerintah terhadap norma subyektif pengusaha.

Pembinaan

berpengaruh positif dan signifikan terhadap norma subyektif pengusaha. Hasil penelitian ini, mendukung temuan Subanar (2001) bahwa meskipun tidak terlihat secara nyata, pengusaha UKM mempunyai saling ketergantung secara moril satu dengan yang lainnya. Di samping itu Suhartono (2008); Thompson dan Panayiotopoulos (1999); Alleyne dan Tracey (2011) juga menemukan faktor norma sosial dan budaya mempengaruhi perilaku pengusaha dalam mengembangkan usahanya. Hasil analisis deskriptif menunjukkan 144 atau $80 \%$ pengusaha setuju bahwa anggota keluarga, rekan bisnis, pemasok bahan baku dan masyarakat sekitar mendukungnya dalam mengembangkan usaha,

4. Pengaruh pembinaan pemerintah terhadap PBC pengusaha

Pembinaan

pemerintah berpengaruh signifikan terhadap PBC pengusaha, mendukung temuan Subanar (2001) bahwa pengusaha yang sukses adalah pengusaha yang mempunyai keyakinan tinggi dalam mengidentifikasi peluang usaha; mampu mengelola sumber daya dan menanggung risiko keputusan bisnis yang diambil. Hasil analisis deskriptif menunjukkan 153 atau 85\% pengusaha mempunyai kemampuan dalam mengidentifikasi peluang, mengelola sumberdaya, membina hubungan dan mematuhi peraturan pemerintah dalam pengembangan usaha.

5. Pengaruh sikap pada pertumbuhan usaha terhadap pertumbuhan usaha.

Sikap pada pertumbuhan usaha berpengaruh positif tetapi tidak signifikan terhadap pertumbuhan usaha. Temuan mendukung Thompson dan Panayiotopoulos (1999) bahwa sikap tidak berpengaruh terhadap keputusan bisnis pada UKM, karena perubahan sikap lebih cepat terjadi pada bisnis kecil dibandingkan dengan perusahaan besar. Sedangkan temuan ini, bertentangan dengan East (1993) bahwa sikap investor berpengaruh signifikan terhadap keputusan investasi. Sikap diwujudkan dalam bentuk penilaian baik-buruk, positif-negatif menyenangkan-tidak menyenangkan,

Jurnal IImu Sosial dan Humaniora | 711 
setuju-tidak setuju. Menurut Brigham (1991) bahwa sikap dapat disimpulkan dari cara-cara individu berperilaku, dapat dipelajari dan mempengaruhi perilaku seseorang dalam mencapai tujuannya. Sikap pada pertumbuhan usaha tidak signifikan mempengaruhi pertumbuhan usaha karena pertumbuhan usaha merupakan proses yang komplek dan dipengaruhi banyak faktor. Jadi pertumbuhan usaha merupakan proses alamiah pengelolaan suatu usaha yang dapat dicapai tanpa harus mempunyai sikap positif pengusaha terhadap pertumbuhan usaha tersebut.

6. Pengaruh Norma Subyektif terhadap

Pertumbuhan Usaha

Norma subyektif berpengaruh positif dan signifikan terhadap pertumbuhan usaha. Temuan ini mendukung Thompson Panayiotopoulos (1999); Venketesh dan Davis, (2000); Suhartono, (2008); Alleyne dan Tracey, (2011) bahwa norma subyektif berpengaruh terhadap keputusan bisnis dan pertumbuhan usaha pada UKM. Hasil penelitian mengindikasikan bahwa UKM pada umumnya berlokasi di daerah pedesaan, merupakan perusahaan keluarga yang dikelola secara turun temurun, sehingga lingkungan sosial lokal mempengaruhi norma subyektif dan perilaku pengusahanya (Granovetter,1985; Aldrich dan Fiol, 1994; Feldman, 1995; Mitchell et al., 2002; Ajzen, 2005; Baron dan Byrne, 2005). Berbeda dengan temuan Davis et al., (1989); Wijaya, (2008) bahwa norma subyektif tidak berpengaruh terhadap perilaku wirausaha baik secara langsung maupun melalui niat berperilaku wirausaha. Hal ini perlu penjelasan lebih lanjut mengenai konsep norma subyektif dari Kelman (1958) yang membedakan tiga proses pengaruh sosial terhadap perilaku seseorang yaitu: kepatuhan, identifikasi dan internalisasi.

7. Pengaruh Perceived behavior control (PBC) pengusaha terhadap pertumbuhan usaha.

PBC pengusaha berpengaruh possitif dan signifikan terhadap pertumbuhan usaha. Mengacu pada Bandura (1986), bahwa konsep self efficacy sama dengan konsep PBC. Hasil penelitian ini mendukung Stajkovic dan Luthans (1989); Boyd dan Vozikis (1994) bahwa self efficacy berpengaruh terhadap kinerja. Berbeda dengan temuan Wijaya (2008); Adam (2012) bahwa PBC tidak berpengaruh terhadap perilaku wirausaha. Perceived behavior control berpengaruh terhadap pertumbuhan usaha pada UKM dengan argumentasi bahwa keputusan pengembangan usaha didasarkan pada kemampuan dalam mengidentifikasi adanya peluang dan mengelola sumber daya yang diperlukan, membina hubungan baik dengan pihak terkait seperti: pemasok, pelanggan dan pemerintah serta ketrampilan manajerial dalam pengembangan usaha tersebut.

8. Sikap pada pertumbuhan usaha memediasi pengaruh pembinaan terhadap pertumbuhan usaha

Sikap pada pertumbuhan usaha tidak terbukti memediasi pengaruh pembinaan terhadap pertumbuhan usaha. Hasil penelitian mengindikasikan bahwa sikap pada pertumbuhan usaha tidak berubah dengan adanya pembinaan dan sikap tersebut juga tidak mempengaruhi pertumbuhan usaha pada UKM. Sejumlah faktor yang diduga

Jurnal IImu Sosial dan Humaniora | 712 
sebagai penyebab karena pembinaan yang diberikan oleh pemerintah tidak tepat sasaran dan prosedurnya cenderung berbelit-belit. Temuan ini mendukung hasil studi Hill (2001); Suhartono (2008) bahwa pembinaan tidak berpengaruh terhadap pertumbuhan usaha pada UKM karena kurang tepat sasaran, tidak ada keseragaman indikator keberhasilan, dan pengusaha UKM hanya sebagai obyek pembinaan. Di samping itu etos kerja pengusaha UKM masih rendah dan cenderung bersikap konservatif dalam mengelola usahanya, menghindari risiko gagal dan pendapatan yang tidak pasti (Saefuloh, 2007).

9. Norma subyektif memediasi
pengaruh pembinaan terhadap pertumbuhan usaha

Norma subyektif memediasi pengaruh pembinaan terhadap pertumbuhan usaha. Temuan ini menunjukkan bahwa pembinaan yang diberikan mampu merubah norma subyektif pengusaha dalam mengelola usahanya sehingga mempengaruhi pertumbuhan usaha pada UKM. Pada umumnya UKM berlokasi di daerah pedesaan, merupakan perusahaan keluarga yang dikelola secara turun temurun, sehingga lingkungan sosial lokal mempengaruhi norma subyektif dan perilaku pengusahanya (Granovetter,1985; Aldrich dan Fiol, 1994; Feldman, 1995; Mitchell et al., 2002; Ajzen, 2005; Baron dan Byrne, 2005). Norma subyektif berpengaruh terhadap keputusan bisnis dan pertumbuhan usaha pada UKM mendukung temuan Thompson Panayiotopoulos 1999; Venketesh dan
Davis, 2000; Suhartono, 2008; Alleyne dan Tracey, 2011.

10. Perceived behavior control (PBC) memediasi pengaruh pembinaan terhadap pertumbuhan usaha.

Perceived behavior control (PBC) memediasi secara positif dan signifikan pengaruh pembinaan terhadap pertumbuhan usaha. Hasil penelitian mengindikasikan bahwa pembinaan yang diberikan pemerintah mampu meningkatkan PBC pengusaha dalam mengembangkan usahanya. Perceived behavior control pengusaha terhadap peluang, sumber daya dan ketrampilan dalam mengambil keputusan bisnis diperlukan untuk menjaga kelangsungan hidup perusahaan di masa yang akan datang. Hasil penelitian ini mendukung temuan Stajkovic dan Luthans (1989); Boyd dan Vozikis (1994).bahwa PBC pengusaha berpengaruh terhadap perilaku wirausaha dan kinerja usaha.

\section{PENUTUP}

Pembinaan

pemerintah berpengaruh signifikan terhadap sikap pada pertumbuhan usaha, norma subyektif dan PBC pengusaha dalam mengembangkan usahanya. Norma subyektif dan PBC pengusaha berpengaruh signifikan terhadap pertumbuhan usaha pada UKM sedangkan sikap pada pertumbuhan usaha tidak. Norma subyektif dan PBC terbukti memediasi pengaruh pembinaan terhadap pertumbuhan usaha. Sedangkan sikap pada pertumbuhan usaha tidak terbukti memediasi pengaruh pembinaan terhadap pertumbuhan usaha pada UKM.

Perlu perencanaan program pembinaan yang lebih tepat sasaran Jurnal IImu Sosial dan Humaniora | 713 
sesuai dengan kebutuhan pengusaha dalam mengembangkan usahanya sehingga mampu merubah sikap, norma subyektif dan PBC pengusaha dalam mengembangkan usahanya. Sikap pada pertumbuhan usaha tidak memediasi pengaruh pembinaan terhadap pertumbuhan usaha sehingga perlu penelitian lebih lanjut untuk mengekplorasi peran pembentukan sikap dalam peningkatan pertumbuhan usaha pada UKM.

\section{DAFTAR PUSTAKA}

Aldrich, H dan M. Fiol, 1994, Fool rush in? The institutional context of industry creation, Academy of Management Review,19, 645-670

Ainuddin, R. A dan H. J. Sa'odah, 2001, Characteristics of EntrepreneurOwned Companies in Malaysia, The Fourth Asian Academy of Management (AAM) Conference 2001 Proceedings Vol I, Johor Bahru, University Sains Malaysia, 133-140.

Ajzen, I., 2005, Attitudes, Personality dan Behaviour. New York: McGraw-Hill Education.

Ali, A., 2011, Predicting Individual Investors' Intention to Invest: An Experimental Analysis of Attitude as a Mediator, International Journal of Human dan Social Sciences.

Alleyne, P. dan B.Tracey, 2011, Using the Theory of Planned Behaviour and Risk Propensity to Measure Investment Intentions among Future Investors, Journal of Eastern Caribbean Studies, Vol. 36

Adam, A., 2012, Socially Responsible in Malaysia: Behavioural Framework in Evaluating Investor's Disision Making Process, Sydney, ACSEAR Conference

Bandura, Albert, 1986, Social Foundation of Thought and Action, Englewood Cliffs, NJ. Prentice Hall Brigham, J.C., 1991. Social Psychology, New York: Harper Collins Publisher.

Boyd, N., dan G. Vozikis, 1994, The influences of self efficacy on the development of entrepreneurial intentions dan actions. Entrepreneurial Theory dan Practice. 18, 63-90

Baron, R. A., D.R. Byrne dan N.R. Branscombe, 2005, Social Psychology, Boston, MA: Allyn \& Bacon.

Barbosa, S.D., M.G. Gerhardt dan J.R. Kickul, 2007, The role of cognitive Style and risk preference on entrepreneurial self-efficacy and entrepreneurial intentions, Journal of Leadership and Organizational studies, 13 (4), 87-104

Chen, C.C., P.G. Greene, dan A. Crick, 1998, Does Entrepreneurial SelfEfficacy distinguish entrepreneurs from Managers? Journal of Business Venturing, 13, 295-316

Collie, T. dan B. A. Sparks, 2000, Perceptions of key success factors dan key success inhibitors in Australian restaurant and catering business operations.

Davis, F.D., R.P. Bagozzi dan P.R. Warshaw, 1989, User acceptance of Computer Technology: A Comparison of Two Theoretical Models, Management Science 35 (8), pp 982-1003

East, Robert, 1993, Investment Dicision dan Theory of Planned Behavior,

Jurnal IImu Sosial dan Humaniora | 714 
Journal of Economic Psychology, 14 (337-375)

Feldman, R.S., 1995, Social Psychology, Theories, Research and applications, New York: McGraw-Hill Book Company

Granovetter, M., 1985, Economic action dan social structure: The problem of embeddedness. American Journal of Sosiologi, 9, 480-5I0

Hill, 2001, Small dan Medium Entreprises in Indonesia, Asian Survey, Vol 4, No 2 pp.248-270

Hair, Joseph F., Jr., William C. Black, Barry J. Babin, Rolph E. Anderson, dan Ronald L. Tatham, 2006, Multivariate Data Analysis, Sixth Edition, New Jersey: Pearson Prentice Hall

Inggarwati, K. dan A. Kaudin, 2010, Peranan factor-faktor individual dalam mengembangkan usaha, Jurnal Manajemen Bisnis Vol 3 No. 2.

Kelman, H.C., 1958, Complience, Identification and Internalization: Three Processes of attitude Change?, Journal of Conflict Resolution 2, pp 51-60.men in Greece,

Kementrian Koperasi dan Usaha Kecil dan Menengah, Peraturan Pemerintah Nomor 32 tahun 1998 Tentang Pembinaan dan Pengembangan Usaha Kecil. Jakarta: Menkop UKM.

Kuncoro, Mudrajad, 2007, Tantangan dan Peluang Ekonomi Kerakyatan dalam Era Globalisasi Ekonomi, Makalah dalam Diskusi Ekonomi Kerakyatan oleh Harian Pikiran Rakyat, Hotel Radison Yogyakarta Mitchell, R.K., J.B. Smith, E.A. Morse, K.W. Seawright, A. Peredo, dan B.
McKenzie, 2002, Are Entrepreneurial Cognitions Universal? Assessing Entrepreneurial Cognitions Across Cultures, Entrepreneurship, Theory dan Practice Summer:932.

Munizu, Musran, 2010, Pengaruh Faktor-Faktor Eksternal dan Internal Terhadap Kinerja Usaha Mikro dan Kecil (UMK) di Sulawesi Selatan Jurnal Manajemen Dan Kewirausahaan, Vol.12, No. 1, Maret 2010: 33-41

Okunlala, J.O., 2011, Effect of Microfinance Organisation on Small and Medium Scale Enterprises in Nigeria, 10th International Entrepreneurship Forum.

Premaratne S.P., 1999, Net wroks, Resources and Small Business Growth: The Experience in Sri Lanka, Journal of Small Business Management Vol 37 No 11 Januari pp. 121-127

Rivani, Veithzal dan Ella J. Sagala, 2010, Manajemen Sumber Daya Manusia untuk Perusahaan, Jakarta Rajawali Press

Stajkovic, A.D., dan F.Luthans, 1989, Self Efficacy dan Work-Related Performance: A Meta Analysis, Psychological Bulletin, 124,240

Subanar, Harimurti, 2001, Manajemen Usaha Kecil, Yogyakarta, BPFE UGM

Sitohang, Sonang, 2003, Pengaruh Kebijakan Pembinaan Pemerintah Terhadap Kinerja Dan Struktur Usaha Sub Sektor Industri Kecil Penggerak Ekonomi Daerah Di Propinsi Sumatra Utara, Ekuitas

Jurnal IImu Sosial dan Humaniora| 715 
Seagal, G., D. Borgia dan J.Schoenfeld, 2005, The Motivation to Become an Entreprenur, International Journal of Entrepreneurial Behavior dan Research, 11, 42-57

Saefuloh, Asep Ahmad, 2007, Kebijakan Pemerintah dalam Pembinaan Pengusaha Kecil dan Menengah (Studi Kasus di Provinsi Bali dan Sulawesi Utara. P3DI Sekjen $D P R-R I$

Suhartono, 2008, Kondisi Usaha Kecil dan Mengengah di Provinsi Bali, antara Kebijakan Kemitraan dan Persaingan, Kajian , Vol 4 No. 3.

Southey, G., 2011, The Theory of Reasoned Action and Planned Behaviour Applied to Business Dicision: $A$ Selective Annotated Bibliography, Journal of New Business Ideas dan Trends.

Thompson, K.E. dan P. Panayiotopoulos, 1999, Prediciting Behavioural Intention in a Small Business Context, Journal of Marketing Practice, 3: 89-96.

Venkatesh, V. dan F.D.Davis, 2000, A Theoretical Extension of The technology Acceptance model: four longitudinal field studies, Management Science 46(2) pp 186-204

Wiklund, J., P. Davidsson dan F.Delmar, 2003,What Do They Think and Feel about Growth? An Expectancy-Value Approach to Small Business Managers' Attitudes toward Growth, Entrepreneurship Theory and Practice 27 (3): 247-269.

Walker, E. dan A. Brown, 2004, What success factors are important to small business owner?, International small business Journal, 22 (6), 577

Wijaya, T., 2008, Kajian Model Empiris Perilaku Berwirausaha UKM DIY dan Jawa Tengah. Jurnal Manajemen dan Kewirausahaan Vol 10 No 2

Zhao, H., S.E. Seibert dan G.E. Hills, 2005, The Mediating Role of Self Efficacy in the Development of Entrepreneurial Intention. Journal of Applied Psychology, 90, 12651271. 